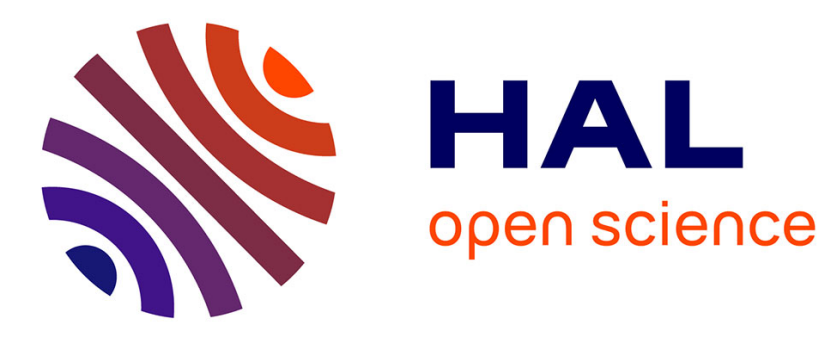

\title{
Clause dependency relations in East Greenlandic Inuit
} Nicole Tersis

\section{To cite this version:}

Nicole Tersis. Clause dependency relations in East Greenlandic Inuit. I.Bril. Clause Linking and Clause Hierarchy, Syntax and pragmatics, John Benjamins, pp.581-601, 2010, Studies in Language Companion Series. halshs-00724096

\section{HAL Id: halshs-00724096 https://shs.hal.science/halshs-00724096}

Submitted on 17 Aug 2012

HAL is a multi-disciplinary open access archive for the deposit and dissemination of scientific research documents, whether they are published or not. The documents may come from teaching and research institutions in France or abroad, or from public or private research centers.
L'archive ouverte pluridisciplinaire HAL, est destinée au dépôt et à la diffusion de documents scientifiques de niveau recherche, publiés ou non, émanant des établissements d'enseignement et de recherche français ou étrangers, des laboratoires publics ou privés. 
Article publié dans Clause Linking and Clause Hierarchy, Syntax and pragmatics, 2010, I. Bril (ed), Amsterdam, John Benjamins, pp.581-601.

\section{Clause dependency relations in East Greenlandic Inuit ${ }^{\mathrm{i}}$}

Nicole Tersis

CNRS-SEDYL

tersis@vjf.cnrs.fr

\section{Introduction}

In the dialects of the Inuit continuum ${ }^{\mathrm{ii}}$, two features ${ }^{\mathrm{iii}}$ of subordination relations in complex sentences stand out: first of all they are characterized by the absence of subordinating elements: subordinate clauses are indicated by markers on the verb; second, there is some structural and formal parallelism between several verb forms found in subordinate clauses and possessive noun phrases.

Taking examples from East Greenlandic, Tunumiisut, I will begin by briefly describing the structure of simple and complex sentences. Complex sentences are defined as a sequence of two or more clauses linked together in a dependency hierarchy ${ }^{\text {iv }}$. In consequence, clause dependency is spread out along a scale. On one end, coordinated clauses which are weakly dependent and which are linked, or not, to the main clause by a coordinator, without any modification of the verb form; on the other end, more strongly dependent subordinate clauses usually indicated by specific verbal markers. Alongside verbal markers indicating subordination, several morphemes within the verb group also mark subordination, as does the presence of a $3^{\text {rd }}$ person referential element which may or may not refer to the agent of the main clause (identity or cross-reference). 
The frequent sequencing of multiple subordinate clauses in narratives and their pragmatic role at discourse level will also be underlined; I will show that the supposed dichotomy between verbal markers in dependent sentences and those in independent sentences seems to be less clear cut in oral discourse, where the relations between clauses go beyond the level of the sentence and reach the level of the paragraph.

I will then explore ways of interpreting a central issue in Inuit morphology - the similarities between possessive noun phrases and subordinate verb forms. To conclude, I will show how, on the typological level, the polysynthetic nature of this language also applies to sentence structure, through the preferential use of synthetic processes to mark clause subordination.

\section{From simple to complex sentences}

Inuit is a SOV language type. In the ergative construction (7b), the nominal agent of a two-argument verb is marked as ergative by $-p$, while the patient is marked as absolutive by a zero marker. In the so-called "antipassive" construction (7c), the single nominal argument of a one-argument verb is in the absolutive $\varnothing$ and the patient is marked by an oblique instrumental case $-m i(k)$, which tends to change into an object marker in less conservative dialects such as East Greenlandic. Pragmatics and definiteness are the main factors which determine the choice of one or the other structure: in $7 \mathrm{~b}$ the topic is niqiq 'the meat' and in $7 \mathrm{c}$ the topic is qimmiq 'the dog'. The change in word order corresponds to pragmatic variation, in particular due to focalization or to the message's explicitation by use of an 'anti-topic' (Tersis \& Carter-Thomas 2005). However one must be aware that interpretation of the sentence's structural analysis, transitivity, word order and ergativity's true nature have been the matter of some debate among linguists over the last ten years, because of the parallelism between 
"transitive" sentences (7b) and possessive noun phrases (Mahieu 2009, Tersis 2004); this phenomenon can be explained from a historical perspective (cf. section 4).

Simple sentences contain a single nominal or verbal predicate. In the former case, the predicate can be a noun, a personal pronoun, a determiner noun or a noun phrase. In this case, word order is subject-predicate.

(1) una qimmiq.

this.one $\operatorname{dog}$

"This one (is) a dog."

(2) taanna uaNa.

ANAPH.this.one mine

"This one (is) mine."

(3) atiwaqpik a ijkkaayuk.

school big

"The school (is) big."

(4) isiqtu-p nunata-a tamaat nunakkaassiaq.

Isortoq-of landscape-3SG all stone

"The Isortoq landscape (is) all stone."

In the latter case, the predicate is a verb which is always followed by a morpheme traditionally defined as a mood marker, and where the person markers are affixed verb-finally, the whole making up a complete sentence. The nominal subject is not mandatory:

(5) nii-wu-q.

eat-IND-3SG 
"He is eating."

(6) nii-wa-Na.

eat-IND-1SG.3SG

"I am eating it."

(7) a. qimmiq nii-wu-q.

dog.ABS eat-IND-3SG

"The dog is eating."

b. qimmi-p niqiq nii-wa-a.

dog-ERG meat.ABS eat-IND-3SG.3SG

"The dog is eating the meat."

c. qimmiq niqi-mi nii-wu-q.

dog.ABS meat-INS eat-IND-3SG

"The dog is eating some meat."

(8) una nii-wu-q.

this.one eat-IND-3SG

"This one is eating."

In simple independent sentences, the verb is followed either by an indicative or an injunctive marker. The final person marker represents the single agent participant of one-argument verbs (7c) or the fusion of the agent and patient participants, for two-argument verbs (7b). The verbal inventory is thus divided into one-argument verbs and two-argument verbs, one must note however that some verbs may do both. The person markers vary according to the valence and the pre-final marker of the verb. Personal 
indexes referring to fused agents and patients show many cases of neutralization and assimilation in Tunumiisut (see Tersis 2000).

The indicative expresses general assertions, noting a past or present fact.

(9) ukiassa-kkit tasiitaqmiit amiqtaniit

autumn-TRANS Tasiilaq.inhabitant.PL many.PL

aatisaq-taq-pu-t aatisakka-ni.

fish-habitual-IND-3PL cod-INS.PL

"In autumn, most of Tasiilaq's inhabitants usually fish for cod."

(10) nutia-kai-kka taki-ssa-wa-tit.

woman-bad-1PL see-FUT-IND-2SG.3PL

"You will see my bad women."

The injunctive expresses moderate injunction.

(11) itii-nia-kkit!

look-INJUNCT-2SG.3PL

"Look at them!"

The sentence with the interrogative and the answer to it (12a-b) although syntactically independent, are of a dependent nature, since they require contextual reference in demanding an answer, a demand or a request.

(12) a. ani-wi-si?

go.out-INTER-2PL

"Are you going out?" 


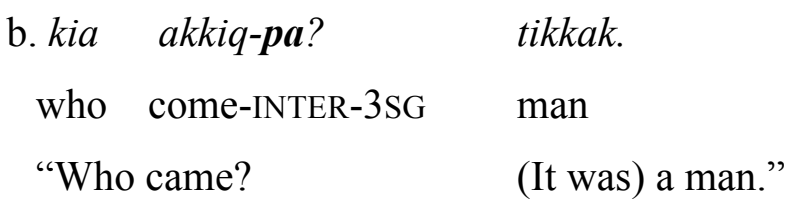

Several verbal predicates may follow one another, forming a complex sentence asyndetically coordinated. First of all we will mention the relatively less frequent case where the clauses of the complex sentence are on the same level without any modification of the verbal forms. Juxtaposed verbal predicates express an enumeration, two simultaneous events, whether the subject is identical or not; this differs from syndetic coordination in that there is no coordinating element between clauses.

$\begin{array}{lll}\text { itisaa-ynita-a } & \text { aassaat } & \text { taki-qnaq-pa-a } \\ \text { recognize-IND.NEG-3SG.3SG } & \text { right.away } & \text { see-1 }{ }^{\text {st }} \text { time-IND-3SG.3SG }\end{array}$
"She doesn't recognize him right away, it is the first time she has seen him."
(14) tikkak qitip-pu-q aаppa-a iqinaqsuq-pu-q. man dance-IND-3SG other-3SG sing-IND-3SG

"One man danced, the other man sang."

In the second case, the verbal predicates and clauses may be coordinated by a medial coordinator, for example aamma "and, also, as well", kisiat "but", qaniq "because", suuq "because of" or clause finally by the clitic coordinators, -tu/-ti "and", -tuunniit/-tiinniit "or else, even", which display vowel harmony with the preceding vowel. Aamma has insistent and additional meaning which the clitic $-t u /-t i$ does not have. Some coordinators may also link nouns $(15 \mathrm{~b}, 16 \mathrm{~b}, 17 \mathrm{~b})$ aamma "and, as well, also", -tu/-ti "and", kisiat "but", while others, such as taa, taawa "so, then" (18), kiisa "finally", qaniq "because" only coordinate clauses. 
(15) a. pisiniaqpi-qaq-pu-q

aamma uqatuppi-qaq-pu-q.

shop-have-IND-3SG

and

church-have-IND-3SG

"There is a shop and there is a church."

b. aatisayaq ataasiq

aamma

timittat

maqtit

fish

one

and

bird.pl

two

"one fish and two birds"

(16) a. innaq-taNaaq-sima-wu-q

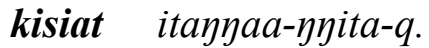

be.in.bed-already-PFV-IND-3SG

but sleep-IND.NEG-3SG

"He is already in bed but he is not sleeping."

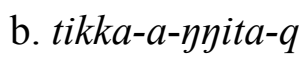

kisiat miqsiqtiq

man-be-IND.NEG-3SG

but child

"He is not a man but a child."

(17) a. miqsiqtit mama-a-kkaayu-u-wa-at

child.PL be.good-find-MOD-be-IND-3PL.3PL

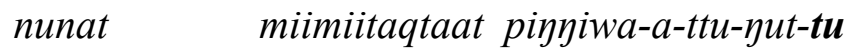

dandelions.PL stalk.PL toy-have.for-CONC-3PL-and

niitassa-a-qati-i-ttu-yut-tu

food-be-together-have.for-CONC-3PL-and

"The children find the dandelion stalks good (indicative), they use them as toys (concomitant) and, at the same time, they use them for food (concomitant)."

b. tikkak naniq-ti

man bear-and 
"the man and the bear"

(18) quttujatiit

suutti-i-ttu-tit

naa-taq-pu-t

leaves.of.willow.PL first-be-CONC-3R.PL grow-habitual-IND-3PL

"It is the willow leaves which grow first,

$\begin{array}{lll}\text { taa } & \text { kiiqna-sigit } & \text { tuqtiiqnat } \\ \text { then } & \text { after-TRANS.3SG } & \text { stonecrop.leaf.PL }\end{array}$

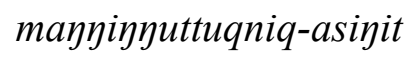

become summer.intensive.fact.of-TRANS.3SG

takkit-taq-pu-t.

come.out-habitual-IND-3PL

then, afterwards, the stonecrop leaves come out, in the middle of summer."

The coordinated clauses take the same verbal moods. In example (17a), the clitic coordinator $-t u /$-ti links the two clauses in the concomitant mood which are dependent on the main clause in the indicative. Although it is possible to coordinate two clauses in the indicative, the presence of the clitic - $t u$ seems to usually be accompanied by the concomitant mood when the agent of the main clause is coreferential with that of the coordinated clause, as also pointed out by Fortescue (1948:120) for West Greenlandic: isirpuq ini-llu-ni-lu /enter.IND.3SG/sit-CONC-3R.SG-and/ "She enters and sits down". The dependency of the coordinate clause is then stronger and close to a subordinate relation, given that it has a specific verbal marker.

When the clauses of a complex sentence are in a subordinate relation, clause dependency is essentially marked by the verb forms.

\section{Dependent clauses and dependent verb forms}


Subordination is characterized by the absence of any subordinator, as in the Samoyed branch of the Uralic family, in particular in Tundra Nenets where there are no subordinating conjunctions, subordination is expressed by subordinate non-finite forms or infinitives and participles (M. A. Mahieu p. c.). In Siberian Yupik, of the Eskaleut family, most subordinating conjunctions are borrowed from the neighboring Chukchi language (Vaxtin, 2000: 316). This situation has led to the reduction of the synthetic processes characteristic of the Eskaleut family (Mahieu and Tersis 2009).

Of the Tunumiisut verbal system (cf. table 1) it is the attributive, concomitant, causative (or effected) and conditional (or non-effected) markers which are most commonly found in subordinate clauses. These markers are followed by a final person and/or number marker. Only oneargument is morphologically marked on verbs in the concomitant, the agent of one-argument verbs and the patient of two-argument ones. The other mood markers can appear with either one-argument or two-argument verbs. In the indicative and the attributive, the one-argument form differs from the two-argument form.

The unmarked clause order is [Subordinate/Main] for dependent clauses of time and manner (cf. 23, 27, 30, 34). The order [Main/Subordinate] is found with certain perception, thought, declarative verbs (cf. 20) in complement clauses or when the dependant clause expresses a logical succession of events (cause-effect), a purpose, a cause (cf. 29). This order is also pragmatically marked, and conveys new information (26a) but can also be caused by the subordinate clause's unwieldiness. Several verbal markers form different subordination types: the attributive introduces complement clauses, the concomitant indicates complement and adjunct clauses (temporal, purpose, cause) with coreferential agent, the causative and the conditional correspond to adjunct subordinate clauses (temporal, manner, cause, consequence or purpose, condition, hypothesis). 
Table 1: Verbal system markers

\begin{tabular}{|c|c|c|c|}
\hline & & One-argument & Two-argument \\
\hline \multirow{3}{*}{$\begin{array}{l}\text { Independent } \\
\text { sentences }\end{array}$} & Indicative & $w u-/+p u-$ & $w a-/+p a-$ \\
\hline & Injunctive & \multicolumn{2}{|c|}{-niaq- } \\
\hline & Interrogative & \multicolumn{2}{|c|}{$w i-/+p i-$} \\
\hline \multirow{4}{*}{$\begin{array}{l}\text { Dependent } \\
\text { clauses }\end{array}$} & Attributive & $-t i-$ & $\eta i-/+k i-$ \\
\hline & Concomitant & $-t t u-$ & \\
\hline & $\begin{array}{l}\text { Causative } \\
\text { (effected) }\end{array}$ & \multicolumn{2}{|c|}{$\eta a /+k a-/ m-$} \\
\hline & $\begin{array}{l}\text { Conditional } \\
\text { (non-effected) }\end{array}$ & \multicolumn{2}{|c|}{$p i /+k i /+p a-$} \\
\hline
\end{tabular}

The consonant variations $w /+p$ and $y /+k$ are subject to the surrounding vowels or to the consonant $(+)$ preceding the verbal marker. Due to amalgamation with the non-coreferential $3^{\text {rd }}$ person marker $-a$, the causative has a variant in $m$ - and the conditional has a variant in $p a-$. We will illustrate the use of each of these forms with a few examples.

\subsection{Attributive}

The single argument attributive - $t i$ - expresses attribution of a specific property, a state, or the durative. Its variant $-s i$ - is conditioned by the preceding consonantal context (cf. 37).

This marker is used as a participial in the $3^{\text {rd }}$ person, serving to modify a noun, tikkak nii-tiq "man eating" (lit. man eat-ATTRIB.SG). This form is translated by certain authors as a relative clause. It also appears as semantically dependent on a preceding sentence, which I define as a form of situational dependency at paragraph level (see 19). Such discursive dependency also appears with other subordination markers (see section 3.5). This means that it cannot appear on its own in an independent sentence, 
contrary to what is found in other Inuit dialects - but not in West Greenlandic (which is more or less like East Greenlandic). It is frequent in discourse, where it is distinguished from the indicative which has a more general meaning and which may appear in independent sentences. It is also found in complement clauses, after thought, perception, and declarative verbs (cf. 20). The verb final person marker represents the agent. In the $3^{\text {rd }}$ person, there is a distinction between same- or cross-reference marked by the index of coreference with the agent of the main clause, -ni or -tit PL. (cf. 19) and by the index of non-coreference $-q$, - $t$ PL (cf. 20).
(19) miqsiqtit tasiita-mut
nuut-taq-pu-t
tattani child.PL Tasiilaq-DIR move-habitual-IND-3PL
there
atiwaqpim-mi
nayuja-qaq-ti-tit.
school-LOC
home-have-ATTRIB-3PL
"The children are used to going to Tasiilaq, there they stay at the school."

\section{(20) taamani \\ at.that.time \\ tasiita-minyaaniit} isima-qaq-ta-yatiwaq-pu-a kuummiit thought-have-habitual-however-IND-1SG
Kuummiit
Tasiilaq-SEP
ani-tii-ti-yumaaq-ti-q. be.big-COMPAR-INCH-FUT-ATTRIB-SG
"At that time, I often thought that Kuummiit (village) would be bigger than Tasiilaq."

Contrary to the one-argument verb of attributive, the two-argument verb of attributive $\eta i-/+k i$ - cannot serve as a noun modifier, but may only be found in the context of situational dependency ${ }^{v}$, or after thought or declarative verbs, as before. The final person marker combines both participants, the agent and the patient. The vocalic variant $y a-/+k a$ - is found before the $3^{\text {rd }}$ person $-a$ due to vowel harmony, as in (21). In the second 
example (22), one finds both the one-argument attributive form modifying the noun siqqut "fins" and the two-argument attributive in the dependent clause.

(21)
isima-qaq-pu-a
kaimi-ya-a.
thought-have-IND-1SG
be.content-ATTRIB-3SG.3SG

"I think he is content with him."

(22)

$\begin{array}{llll}\text { siqqut } & \text { uti-sima-ti-t } & \text { ukiiq } & \text { tamaat } \\ \text { fin.PL } & \text { pluck-PFV.ATTRIB-PL year } & \text { all } \\ \text { aaqqissii-niqas-sinnaa-ppu-t } & & \text { kisiat } \\ \text { prepare.INTR-PASSIF-be.able-IND-3PL } & \text { but }\end{array}$

$\begin{array}{lll}\text { nii-tii-ta-Ni-pput } & \text { niitassat } & \text { mayniniq-mi } \\ \text { eat-COMPAR-HAB-ATTRIB-1PL.3PL } & \text { food.PL } & \text { summer-LOC }\end{array}$

"Plucked fins may be prepared all year, but we are used to eating more food in summer."

In this last example, it would be possible however to have the indicative in the coordinated sentence after kisiat "but", to express a general fact and not a specific property.

\subsection{Concomitant}

The concomitant -ttu- (the more usual term is contemporative) is used with one-argument valence in subordinate clauses expressing actions simultaneous or contemporary to those expressed in the main clause (23), with temporal or manner specification, or in purpose clauses where the action participates in the main action (cf. 25). The agent is generally identical in the main and dependent clauses. The referential third person marker refers either to the agent (cf. 24) -ni (3R.SG)/-tit (3R.PL), as a 
reflexive person, or to the patient (cf. 25) - $\eta u$ (3SG)/-yut (3PL). The most common order is for the subordinate clause to come first. This order may be reversed for semantic reasons (expressing manner), or for focalization purposes (26a), or because the sentence becomes too unwieldy when the three dependent clauses with the concomitant come in succession, or lastly after a declarative verb such as 'say', in which case the complement clause cannot be preposed (cf. 26c).

$\begin{array}{lll}\text { (23) } \text { miqsiqti-i-ttu- } a & \text { tattani } & \text { atiwaq-ti-wa. } \\ \text { child-be-CONC-1SG } & \text { there } & \text { go.to.school-ATTRIB-1SG }\end{array}$

"When I was a child, I went to school there."

(24) suti-ttu-ni aattaq-tip-pu-q.

work-CONC-3R.SG begin-INCH-IND-3SG

"He is starting to work"

(25) uqni-ttu- $\eta u$

ani-wu-q.

meet-CONC-3SG

go.out-IND-3SG

"He is going out to meet him."

(26) a.[mamaa-kkaayu-u-pa-qput]

[kataatti-i-ttu-ta]

think.good-a.lot-be-IND-1 PL-3SG

Greenlander-be- CONC-1PL

mattak.

narwhal skin

"We think it is very good (indicative), we who are Greenlanders, (concomitant) narwhal skin."

b.[aatisakkat pani-qqissaq-sima-yyit-sit

cod.PL be.dry-completely-PFV-NEG-ATTRIB.PL

[uu-ttu-yut $] \quad$ [taawaa aammaqqaa-ttu- $y u t]$ 


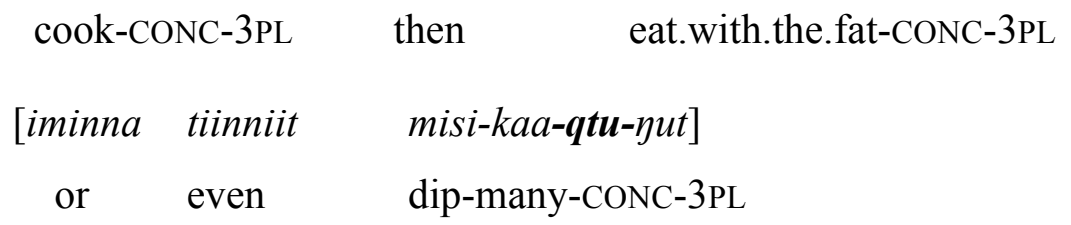

nii-taq-pa-qput].

eat-habitual-IND-1PL.3PL

"We are used to eating (indicative) cod which are not quite dry (attributive, equivalent to a relative clause) by cooking them (concomitant) and mixing them with fat (concomitant) or even by dipping them (concomitant) several times (in oil)."
c. $u q a q-p u-q$
akki-ssa-ttu- $\eta u$.
say-IND-3SG
come-FUT-CONC-3SG

"He said he was going to come."

\subsection{Anteriority and effected processes}

The causative (to use the term traditional in Inuit studies) or the effected marker $\mathrm{ya}-/+\mathrm{ka} / \mathrm{m}$ - in subordinate clauses refers to a past action, to an action preceding either another action or the time of speech, or a causalexplicative relation when the subordinate clause is postposed (29). The $3^{\text {rd }}$ person marker may indicate reference identical to that of the main clause agent -ni $(\mathrm{sg}) /$-tit $(\mathrm{pl})$ or without coreference -a/-at to the agent of the main clause. The same is true in the conditional, for both one- and two-argument forms.

(27) nii-ya-ma

eat-CAUS-1SG

"After I ate, he worked." suti-wu-q.

work-IND-3SG 
(28) itii-ya-kkit

look.at-CAUS-1 SG.2SG atiwaq-pu-tit.

read-IND-2SG

"When I looked at you, you were reading."

(29) kutusu-p mittaqpi-a aqqissii-niqaq-pu-q

Kulusuk-of airport-3SG build.INTR-PASSIVE-IND-3SG

nuna-ta-a manis-sii-Naaq-m-at.

ground-part-3SG be.flat-COMPAR-time.when-CAUS-3SG

"The Kulusuk airport was built because the ground was flatter."

\subsection{Posteriority and non-effected processes}

The $\eta i-/+k i / p a-$ markers express non-effected actions, an action posterior to another one, cause-effect relations, hypotheticals. The $\eta i$ - form has the variant $-\mathbf{N i}$ - when the preceding consonant is the uvular/q/. The affix-yiaq- and its variants -Niaq-, -Vyaq- "at the time when" often precedes the conditional (cf. 3.5.).

(30) tiki-ya-Ni-ma

come-time.when-COND-1SG

"When I come, he will go out." ani-ssa-wu-q.

go.out-FUT-IND-3SG

(31) itii-nia-Ni-kku ittuu-ti-ssa-wu-q. look.at-time.when-COND-1SG.3SG be.bothered-INCH-FUT-IND-3SG "When I look at him, it will bother him."

(32) a. kataati-i-ttu-ta

Greenlander-be-CONC-1PL niqiut-taq-pu-ut

hope-HABIT-IND-1 PL 


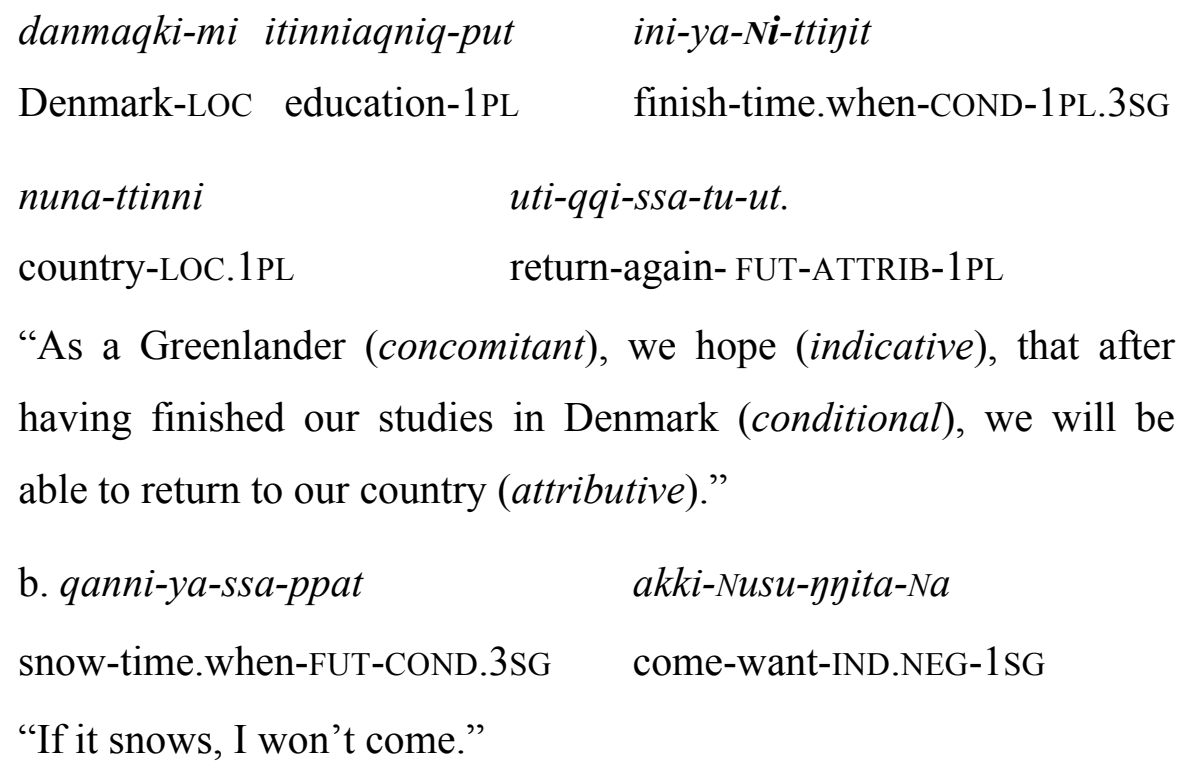

These examples show the dichotomy noted by scholars of Inuit, i.e. the clear distinction between the indicative, the interrogative and the injunctive which are found in independent sentences, and the attributive, the concomitant, the causative and the conditional which appear in subordinate clauses (see table 1).

\subsection{Clause chains in oral discourse}

However, in the structures of narratives, this dichotomy is not always so clear-cut, as shown by discourse analyses (Berge 1997, Fortescue 1984 for Greenlandic, Jacobson 1995, Mithun 1996, Mather, Meade \& Miyaoka 2002, Woodbury 1985 for Alaskan Yupik). Here is an example taken from a story in Tunumiisut where it seems that several complex sentences have no indicative marker and, consequently, no main clause, but only verbal markers which are usually reserved for subordinate clauses, since they are pragmatically linked to the preceding utterances. For example in (33), the complex sentence has two effected verb forms (in the causative) 
and one concomitant, all of which depend on a clause situated much earlier in the paragraph, which is in the indicative.

(33)

\author{
qitiiqtaa- Na-mii \\ untie-CAUS.3SG.3SG
}

pii- Na-mii

remove-CAUS-3SG.3SG $\begin{array}{ll}\text { nanni-p } & \text { assinaaqta-ni } \\ \text { bear-from } & \text { rope.in.skin-3SG }\end{array}$

ani-qqi-tti-ni-ti.

go.out-anew-CONC-3R.SG-and

"After having untied it, he removed the rope from the bear and went out again."

Furthermore, oral narratives clearly show that dependent sentences are highly frequent. In a given story, $69 \%$ of the sentences are dependent clauses and only $31 \%$ are independent, whence the notion of clause chains anchored in an initial clause on the paragraph discourse level ${ }^{\mathrm{vi}}$. On a pragmatic and discursive level, the role of subordinate clauses with causative verb forms is essential, as it serves to retain the listeners' attention with explicative or "background" information up until the announcement of the major information contained in the main clause (Kalmar 1982); subordinate clauses also present the various phases of an event. For example in (34), at the beginning of a story, one sees the sequence of two causatives and one concomitant before the main clause in the indicative. In the same narrative, one counts a majority of $43 \%$ of causative verb forms in the dependent clauses (Grove and Tersis, forthcoming).

(34) [nunaqqati-qati-yii-ppatiwa-kaiit

living-together-mutual-numerous-INTENSIVE

tusaa-ya-Naa-tiq-m-ata]

listen-time.when-many-INCH-CAUS-3PL

[piaNiiqsa-qti-tit ] [aatta-kaa-Naaq ${ }^{\mathrm{vii}}$-tiq-m-ata] 
prepare-CONC-3R.PL leave-numerous-many-INCH-CAUS-3PL

[qaNanisa-kaiit kiissaaq-mi itti-p iti-wa-ni

old.man-poor.PL alone-INS house-of inside-3SG-LOC

paaqsi-ti-ssa-yyiq-pu-t].

keep-ATTRIB- FUT-become-IND-3PL

"Whereas a lot of people from the same village were all going together, lots of them, to listen to stories (causative), while they were getting ready (concomitant marking simultaneity between the process and the following one) to all leave together (causative), two unfortunate old men stayed behind (indicative) alone to guard the house."

Moreover there are several conjunctive morphemes internal to the verbal group which also mark clause dependency. Here are some examples.

\subsection{Conjunctive morphemes}

Several conjunctive morphemes frequently appear in dependent sentences, either alone or in succession, in particular: -niaq- "while, whereas", -niaq- (variant -Niaq-, -(V)yaq-) "at the time when, each time that", -yaaq- (variant -Naaq-) "when, each time that":

(35) іпиүұи-иуа-a-ma

be.born-time.when-CAUS-1SG

"When I was born, we lived there."

(36) asimiuqaqpin-ni village-INS.PL
"When I was born, we lived there."
atta-ni
other-INS.PL

tattani nayunaqaq-pu-ut.

there live-IND-1PL

village-INS.PL 
ayata-aya-SSa-Yaa-Na-mit

kutusu-mingaaniit

travel-time.when-FUT-when-CAUS-3PL.COREF Kulusuk-SEP

itikuptiqi-ni timmi-taq-pu-t.

helicopter-INS.PL fly-HABIT-IND-3SG

"When they are going to travel to the other villages, they take the helicopter coming from Kulusuk."

The conjunctive morphemes -niaq- and yiaq-/-(V)yaq-also appear in other contexts however, albeit in independent sentences with a different identity. Taking some examples, one might wonder how to interpret them: is it a case of grammaticalization within the affix inventory? Or should one consider, on the contrary, that it is a single affix entering different combinations, and thereby having different temporal and modal meanings?

On this point, the morpheme -niaq- is particularly instructive. In dependent sentences, it means "while, whereas, at the time when"; it marks that the process covers a certain time span and can be followed by attributives, concomitants, causatives or interrogatives:

\author{
(37) tattani puta-sima-nia-qti-ni sitaq \\ there enter-PFV-time.where-CONC-3R.SG outside \\ taqqa-a-si-tiq-siq. \\ shadow-be-become-INCH-ATTRIB.SG \\ "When she went in there, outside it got dark."
}

This same morpheme -niaq- is also found after nouns, with the meaning "hunt", as an incorporating verb which is always suffixed (38), or after a verb, as conative verbal modality with the meaning "try, seek to" (39), or as a marker of moderate injunction. The semantic denominator common to these different uses is that of intention / conation (Tersis 2008): 
-niaq-1 incorporating $N-V(-)$ verb 'hunt'

(38) miikkattaq-niaq-pu-q.

ringed.seal-hunt-IND-3SG

"He hunts ringed seal."

-niaq-2 verbal modality $V-V$ 'seek to, try, have the intention of'

(39) suutti-i-niaq-pu-q.

first-be-try-IND-3SG

"He is trying to be first."

-niaq- 3 moderate injunctive

(40) nii-niaq-ta!

eat-INJUNCT-2PL

"Let's eat!"

The morpheme -yiaq-/-Vyaq- has the meaning "when, each time that" in dependent clauses, and is most often preposed to the conditional marker (cf. 30). It is also found in main clauses with the meaning "suddenly, at the time when" (41):

(41)
isi-yaq-pu-q
itaqutat nii-ti-t.
enter-time.when-IND-3SG
family.PL
eat-ATTRIB-3PL

"When he came in the family was eating."

The etymological form of yiaq-/-Vyaq- could be linked to a Proto-Inuit inchoative morpheme: * riaq- and *Riaq- 'set about-ing' (Fortescue et al. 1994: 398). The morpheme yaaq- "when, each time that" only appears in dependent clauses with the causative and the concomitant. It might be related to Proto-Inuit * yaa- and *-yai- 'whenever' (Fortescue et al. 1994: 398). 
One of the most striking features of certain dependent verb forms, namely the causative and the conditional, is however their structural and formal similarity to possessive noun phrases. I will first present data and will then draw some conclusions from them.

\section{Subordination and possessive noun phrases}

The entire set of person markers for causative (effected) and oneargument conditional (non-effected) verb forms are identical in form to possessor markers in possessive modification involving two nouns (cf. table 2).

-Possessive modifiers

$$
\begin{array}{lll}
\text { anaana-ma } & \text { ati-a } \boldsymbol{a} & \text { "my mother's name" } \\
\text { mother-1SG } & \text { name-3SG }
\end{array}
$$

-Subordinate clause

$$
\begin{array}{ll}
\text { nii-ya-ma } & \text { suti-wu-q. } \\
\text { eat-CAUS-1SG } & \text { work-IND-3SG }
\end{array}
$$

"When I was eating, he was working."

One must remember that in a possessive relation between two nouns, the junctor (genitive) $-p$ "of" governs the modifier (the possessor) and the $3^{\text {rd }}$ person marker $-a$ is suffixed to what is possessed, modified: 
(45)

$$
\begin{array}{lll}
\text { qimmi-p } & \text { suuni-a } & \text { "the dog's head" } \\
\text { dog-of } & \text { head-3SG }
\end{array}
$$

The morphophonological analysis of the verb forms in the causative (see Table 2) shows elements shared with nouns, such as the junctor $-p$ and the person markers:

(46) anaana-ma "of my mother's"
|anaana-p-ya ।
mother-of-1SG
nii-na-p-na ।
eat-CAUS-of-1SG

nii-ya-ma "when I was eating"

Synchronically, this indicates convergence between the possessive noun phrase and the verb phrase in certain subordinate clauses. The possessor and the possessee are in a dependency relation just like a clause with a verb in the causative or the conditional is in a relation of dependency to the main clause.

\begin{tabular}{|c|c|c|}
\hline & Singular & Plural \\
\hline 1. & $\begin{array}{l}\text { nii-ya-ma } \\
\text { Inii-ya-p-ya । } \\
\text { eat-CAUS-of-1sG } \\
\text { 'when I was eating' }\end{array}$ & $\begin{array}{l}\text { nii-ya-tta } \\
\text { Inii-na-p-ta । } \\
\text { eat-CAUS-of-1PL } \\
\text { 'when we were eating' }\end{array}$ \\
\hline 2. & $\begin{array}{l}\text { nii-ya-wit } \\
\text { Inii-ya-p-tit । } \\
\text { eat-CAUS-of-2SG } \\
\text { 'when you were eating' }\end{array}$ & $\begin{array}{l}\text { nii-ya-ssi } \\
\text { Inii-ya-p-si । } \\
\text { eat-CAUS-of-2PL } \\
\text { 'when you (pl) were eating' }\end{array}$ \\
\hline \multirow[t]{2}{*}{3 . } & \multicolumn{2}{|c|}{ Coreference with the agent in the main clause } \\
\hline & $\begin{array}{l}\text { nii-ya-mi } \\
\text { Inii-na-p-ni । } \\
\text { eat-CAUS-of-3SG } \\
\text { 'when he was eating' }\end{array}$ & $\begin{array}{l}\text { nii-ya-mit } \\
\text { Inii-ya-p-ni-t । } \\
\text { eat-CAUS-of-3PL } \\
\text { 'when they were eating' }\end{array}$ \\
\hline \multirow[t]{2}{*}{3.} & \multicolumn{2}{|c|}{ Non-coreference with the agent in the main clause } \\
\hline & $\begin{array}{l}\text { nii-mm-at } \\
\text { Inii-y(a)-p-at । } \\
\text { eat-CAUS-of-3SG } \\
\text { 'when he was eating' }\end{array}$ & $\begin{array}{l}\text { nii-mm-ata } \\
\text { Inii-n(a)-p-ata । } \\
\text { eat-CAUS-of-3PL } \\
\text { 'when they were eating' }\end{array}$ \\
\hline
\end{tabular}

Table 2: The causative or effected single argument; the verb nii- "eat" 
In the morphophonology one notes the presence of the plural form -nit instead of -tit for the $3^{\text {rd }}$ coreferential person, probably by analogy with the singular -ni. Some morphophonologically irregular forms might correspond to different evolutive stages of the language.

These forms are parallel to those expressing possessive relations in noun phrases, except that the singular/plural distinction is neutralized in the $3^{\text {rd }}$ person. The same is true for the one-argument conditional.

$\begin{array}{clll}1 \mathrm{sg} & \begin{array}{l}\text { qimmi-ma } \\ \text { dog-of.1SG }\end{array} & \begin{array}{l}\text { suuni-a } \\ \text { head-3SG }\end{array} & \text { "my dog's head" } \\ 2 \mathrm{sg} & \begin{array}{l}\text { qimmi-wit } \\ \text { dog-of.2SG }\end{array} & \begin{array}{l}\text { suuni-a } \\ \text { head-3SG }\end{array} & \text { "your dog's head" } \\ 1 \mathrm{pl} & \begin{array}{l}\text { qimmi-tta } \\ \text { dog-of.1PL }\end{array} & \begin{array}{l}\text { sunni-a } \\ \text { head-3SG }\end{array} & \text { "our dog's head" } \\ \text { 2pl } & \begin{array}{l}\text { qimmi-si } \\ \text { dog-of.2PL }\end{array} & \text { sunni- } a & \text { "your dog's head" } \\ & & \end{array}$

$3 \mathrm{sg} / \mathrm{pl}$ coreferential with the sentence agent:

$\begin{array}{lll}\text { qimmi-mii } & \text { suuni-a } & \text { "his/their dog's head" } \\ \text { dog-of.3SG } & \text { head-3SG }\end{array}$

$3 \mathrm{sg} / \mathrm{pl} \mathrm{non-coreferential} \mathrm{with} \mathrm{the} \mathrm{sentence} \mathrm{agent:}$

$\begin{array}{ll}\text { qimmi-ata } & \text { suuni-a } \\ \text { dog-of.3PL } & \text { head-3SG }\end{array}$


This symmetry has given rise to the interpretation that the verbal clause was essentially nominal, an interpretation which has been reinforced by the existence of the same parallelism between the possessive forms for nouns (47) and the two-argument verb forms in the indicative in independent clauses (48). The entire verb system could thus be interpreted as participial nominalized forms (-wu-/-wa- assertion, -ti-/- $\eta i$ - durative, -ttuconcomitance, $-\eta a$ - effected, $-\eta i$ - non-effected).

(47)

$\begin{array}{lc}\text { qimmi-kka } & \text { "my dogs" } \\ \text { qimmi-tit } & \text { "your dogs" } \\ \text { qimmi-t } & \text { "your dog" } \\ \text { qimmi-a } & \text { "his dog" }\end{array}$

(48)

$\begin{array}{ll}\text { taki-wa-kka} & \text { "I see them" } \\ \text { taki-wa-tit } & \text { "you see them" } \\ \text { taki-wa-t } & \text { "you see him" } \\ \text { taki-wa-a } & \text { "he sees him" }\end{array}$

However, there are a certain number of discrepancies between structures belonging to different levels (possessive phrases and subordinate clauses). Several linguists have been led to consider that the nominal interpretation is only valid from a historical perspective, and that synchronically, it is a case of verbal conjugation on the one hand and of noun phrases on the other, with no possibility of their being one and the same phenomenon:

"yes, there is indeed a parallel, with some morphological communality, but no, the verbal and nominal constructions can not simply be equated, synchronically or diachronically." (Fortescue 1995: 62). 
The origin of two-argument verb forms is to be found in $3^{\text {rd }}$ person possessed passive participial constructions which spread throughout the verbal system (Fortescue 1995: 67). "Thus the ancestor of sentence: pinaqtu-p terianniaq taku-va-a /hunter-REL/fox.ABS/see-3SG.3SG/ "the hunter saw the fox" could be construed as "the hunter's seen thing (was) the fox", no longer a nominal construction used predicatively but the blend of such a nominal construction with normal clause syntax".

In particular, in the subordinate clause, the possessive structure is not wholly symmetrical, as the verbal predicate in the main clause has no specific marker, contrary to the possessed element in the possessive relation, which is always followed by the non-coreferential $3^{\text {rd }}$ person marker $-a$. To use Nichols's (1986) terms, this structure is marked twice, whereas in the complex sentence, only the subordinate clause is marked, thus constituting a "truncated possessive relation". Furthermore, the chaining of subordinate clauses is possible and frequent, whereas there is no such chaining of possessive noun phrases (Woodbury 1985). Moreover, word order in the possessive phrase is set, while it is flexible in the subordinate clauses, subject only to semantic or pragmatic criteria (Berge 1997).

One must also note that the parallelism does not affect all of the verbal system's forms. Nominal and verbal inflections only partially overlap. In particular, reference to the agent and the patient word-finally, is not identical for all of the two-argument verb forms, whether in independent or dependent clauses. The $3^{\text {rd }}$ person agent (50) does not receive the same treatment as the $1^{\text {st }}$ and $2^{\text {nd }}$ person agent (49), according to the morphophonological analysis which makes it possible to account for the numerous amalgamations and deletions in Tunumiisut (Tersis 2000). Furthermore, reference to the agent and patient are reversed for reasons of person hierarchy. Parallelism between possessives and verb forms in independent clauses, or even dependent ones, is not valid when the agent is 
a $3^{\text {rd }}$ person (50): in this case, a patient is added word finally which has no correspondent among the possessive forms:

Marker order: patient-agent

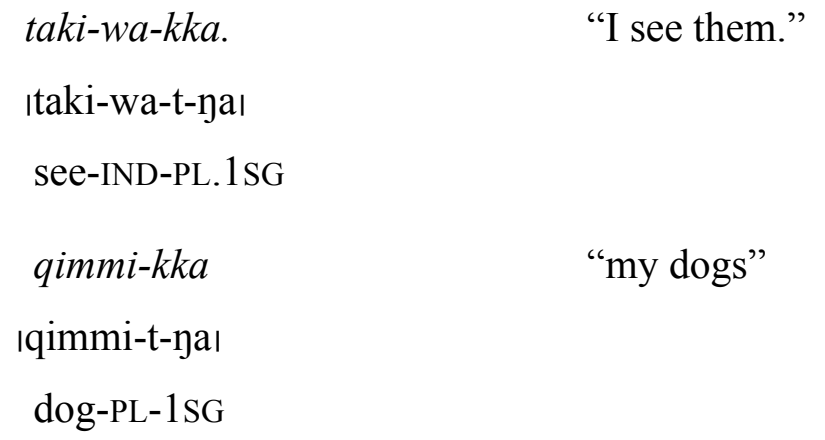

Marker order: agent-patient

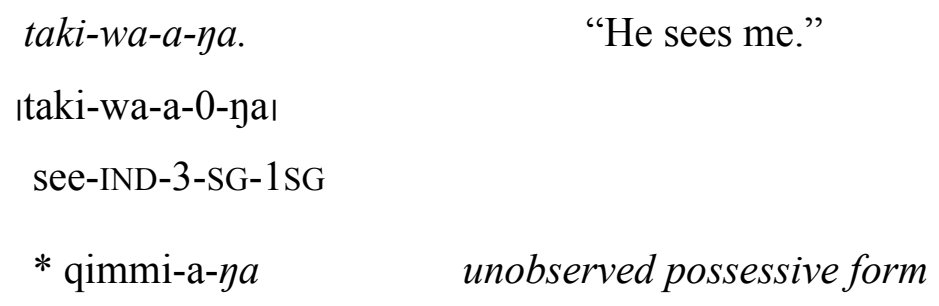

"He sees me."

Historically, K. Bergsland (1989: 31) posits anteriority for the causative and conditional dependent verb forms as compared to the independent verb forms. He reconstructs a morpheme *m to mark dependency after one-argument causative verb forms, which is followed by a personal pronoun which became cliticized into a person marker (see Mahieu 2009). This morpheme ${ }^{*} \mathrm{~m}$ would then have become specialized as a genitive marker following the noun. M. Fortescue (1995) notes that, according to this hypothesis, forms with a dependency marker would have first characterized dependent clauses, and then would have spread to the independent forms of two-argument indicatives. The parallelism between possessive noun phrases and dependent constructions, in complex sentences, would therefore be due to historical, formal and semantic reasons, because 
of the link existing between a clause's possessor and agent: this convergence between nominal and verbal dependency could attest to a property of this linguistic system. This flexibility would make it possible to use, after both nouns and verbs, the same morphemes -resulting from the fusion between a person marker and a dependence morpheme. The parallelism might have weakened and grown opaque in time.

\section{Conclusion}

In Inuit, subordinating verbal forms have both syntactic and pragmatic functions, since they also link clause chains which are contextually dependent on preceding utterances. An analysis of oral texts shows the pragmatic importance of subordination and the frequency of several successive subordinate clauses. The distinction between verb forms appearing in dependent and independent clauses for pragmatic reasons should thus be minimized, and dependency phenomena should be considered at a higher level, the level of the discursive paragraph. Similarly, the notion of 'situational dependency' inherent to the attributive verbal marker and to the other subordinate verbal markers should be broadened.

Subordination marked by specific verb forms shows the clearest type of dependency. Two types of hierarchy are distinguished in subordination: complement clauses which are postposed to the main clause and are characterized by the attributive or concomitant verb markers, and adverbial clauses which are preposed to the main clause -with certain possibilities however for displacement for semantic and/or pragmatic reasons- and which is characterized by the concomitant, causative and conditional verbal markers.

Furthermore, the various devices used to mark subordinate clauses in East Greenlandic Inuit -namely specific verb forms, affixes included in the 
verb phrase and coreferential person markers- highlight the compactness of complex sentences and the importance of the synthetic means used in clause dependency relations at clause or discourse levels. These devices are in keeping, on the typological level, with the language's polysynthetic structure. The structural homology between possessive noun phrases and adverbial clauses with the causative and conditional verb forms contributes to reducing the number of subordination markers and to reinforcing the cohesion of complex sentences.

A study of the textual structure which would also include pauses, intonation and the role of discourse particles would make it possible to further explore the specificity of dependent clauses within oral Inuit discourse.

$\begin{array}{ll}\text { Abbreviations } \\ \text { morphophonological analysis } \\ \text { ABS } & \text { amalgam } \\ \text { ANAPH } & \text { anaphoric } \\ \text { ATTRIB } & \text { attributive } \\ \text { CAUS } & \text { causative } \\ \text { COMPAR } & \text { comparative } \\ \text { CONC } & \text { concomitant } \\ \text { COND } & \text { conditional } \\ \text { DIR } & \text { directive } \\ \text { ERG } & \text { ergative } \\ \text { FUT } & \text { future } \\ \text { INCH } & \text { inchoative } \\ \text { IND } & \text { indicative } \\ \text { INJUNCT } & \text { injunctive }\end{array}$




$\begin{array}{ll}\text { INS } & \text { instrumental } \\ \text { INTER } & \text { interrogative } \\ \text { INTRANS } & \text { intransitivizer } \\ \text { LOC } & \text { locative } \\ \text { MOD } & \text { modifier } \\ \text { NEG } & \text { negation } \\ \text { PFV } & \text { perfective } \\ \text { NOM } & \text { nominative } \\ \text { 3R.SG/PL } & \text { third reflexive person singular/plural } \\ \text { REL } & \text { relative } \\ \text { SEP } & \text { separative } \\ \text { SG } & \text { singular } \\ \text { PL } & \text { plural } \\ \text { TRANS } & \text { translative }\end{array}$

\section{References}

Berge, Anna. 1997. Topic and Discourse Structure in West Greenlandic, Agreement Construction. Berkeley: University of California. Mimeographed.

Bergsland, Knut. 1989. Comparative Aspects of Aleut Syntax. Aikakauskirja /Journal de la Société Finno-ougrienne 82:7-80.

De Reuse, Willem J. 1988. Studies in Siberian Yupik Eskimo.Morphology and Syntax. Austin: University of Texas.

DORAIS, Louis-Jacques. 1996. La parole inuit. Langue, culture et société dans l'Arctique nord-américain. Paris: Peeters.

Fortescue, Michael. 1984. West Greenlandic. Croom Helms Descriptive Grammars. London-Beckenham: Croom Helm.

ForTescue, Michael. 1995. The Historical Source and Typological Position 
of Ergativity in Eskimo Languages. Etudes/Inuit/Studies 19 (2): 61-75. Fortescue, Michael, Jacobson, Steven A. \& Kaplan, Lawrence. 1994. Comparative Eskimo Dictionary with Aleut Cognates. Fairbanks: Alaska Native Language Center.

Grove, Arnaq \& Tersis, Nicole. Forthcoming, Structure and gesture in Greenlandic Oral Tradition, Tales from Eastern Greenland. Manuscript.

JaCobson, Steven. 1995. A Practical Grammar of the Central Alaskan Yup'ik Eskimo Language. Fairbanks: Alaska Native Language Center.

KALMAR, Ivan. 1982. The Function of Inuktitut Verb Modes in Narratives Texts. In Tense-Aspect: Between Semantics and Pragmatics, P. Hopper (ed), 45-64. Amsterdam: John Benjamins.

KAPLAN, Lawrence. 2000. L'inupiaq et les contacts linguistiques en Alaska. In Les langues eskaléoutes, Sibérie, Alaska, Canada, Groenland, N. TERsIS \& M. Therrien (eds.), 91-108. Paris: CNRS Editions.

Lowe, Ronald. 1991. Les trois dialectes inuit de l'Arctique canadien de l'Ouest: analyse descriptive et comparative. Groupe d'Etudes Inuit et Circumpolaires. Québec: Université Laval.

MaHIEU, Marc-Antoine. 2009. Objective Conjugations in Uralic and Eskaleut: Evidence from Inuit and Mansi". In Variations on Polysynthesis: the Eskaleut Languages, M.-A. Mahieu \& N. Tersis (eds). Typological Studies in Language. Amsterdam: Johns Benjamins.

MAHIEU, Marc-Antoine \& Tersis, Nicole (eds). 2009. Variations on Polysynthesis: the Eskaleut Languages, Typological Studies in Language. Amsterdam: Johns Benjamins.

Mather, Elsie, Meade, Marie \& MiYaoka, Osahito. 2002. Survey of Yup 'ik Grammar Revised. Endangered Languages of the Pacific Rim A2-023. Kyoto: Nakanishi Printing Co. 
MenneCIer, Philippe. 1995. Le tunumiisut, dialecte inuit du Groenland oriental. Description et analyse. Paris: Klincksieck.

Mithun, Marianne (ed).1996. Prosody, Grammar, and Discourse in Central Alaskan Yup'ik. Santa Barbara Papers in Linguistics 7. Santa Barbara: University of California.

Mithun, Marianne. 2008. The Extension of Dependency beyond the Sentence. Language 84: 69-119.

MiYAOKA, Osahito. 1996. Sketch of Central Alaskan Yupik, an Eskimoan language. In Handbook of North American Indians. Vol. 17. Languages, I. Goddard (ed.), Washington, D.C.: Smithsonian Institution, 325-363.

NiCHOLS, Johanna.1986. Head-Marking and Dependent-Marking Grammar, Language 62: 56-119.

ROBERT, Stéphane. 1996. Aspect zéro et dépendance situationnelle: l'exemple du wolof. In Dépendance et intégration syntaxique, C. Muller (ed), 153-161. Tubingen: Max Niemeyer Verlag.

SADOCK, Jerrold. 2003. A Grammar of Kalaallisut (West Greenlandic Inuttut). Languages of the World/Materials 162. Lincom Europa.

TERSIS, Nicole. 2000. Economie structurelle et complexité syntagmatique, Groenland oriental. In Les langues eskaléoutes. Sibérie, Alaska, Groenland, N. Tersis \& M. Therrien (eds), 249-268. Paris: CNRS Editions.

TERSIS, Nicole. 2004. De l'ergatif à l'accusatif, évolution des structures argumentales en inuit du Groenland In Actes du Colloque Ergativité, F. Queixalos (ed), 45-51. Villejuif: Centre d'Etudes des Langues Indigènes d'Amérique (CNRS, IRD).

TERSIS, Nicole. 2008. Forme et sens des mots du tunumiisut, lexique inuit du Groenland oriental, lexique tunumiisut-anglais-danois. Paris: Peeters. 
Tersis, Nicole \& CArTer-Thomas, Shirley. 2005. Integrating Syntax and Pragmatics: Word Order and Transitivity Variations in Tunumiisut. International Journal of American Linguistics: 473-500.

VAXTIN, Nicolaj B. 2000. Les différents types de phrases polyprédicatives du yupik sibérien central. In Les langues eskaléoutes, Sibérie, Alaska, Canada, Groenland, N. Tersis \& M. Therrien (eds), 303333. Paris: CNRS Editions.

Woodbury, Anthony. 1985. Noun, Nominal Sentence and Clause in Central Alaskan Yupik Eskimo. In Grammar inside and outside the Clause, J. Nichols \& A. Woodbury (eds), 61-88. Cambridge: Cambridge University Press.

I We would like to thank Isabelle Bril (LACITO-CNRS), Michael Fortescue (University of Copenhagen) and Francisco Queixalos (CELIA-CNRS) for their helpful comments and insightful suggestions on an earlier version of this paper.

ii The Inuit continuum spans from northern Alaska to Greenland; it belongs to the Eskaleut (Eskimo-Aleut) family and constitutes a homogeneous set of sixteen dialects with approximately 80000 speakers. Tunumiisut is spoken in the easternmost part of the dialect continuum by approximately 3577 people, out of an estimated total Greenland population of 56969 , according to statistics compiled in 2005 .

iii These traits are found throughout the Inuit dialects, from northern Alaska to Greenland (cf. Dorais 1996, Fortescue 1984, Kaplan 2000, Lowe 1991, Mennecier 1995, Sadock 2003) as well as in the Yupik languages belonging to the same linguistic family (de Reuse 1988, Jakobson 1995, Mithun 1996, Miyaoka 1996). 
iv The term 'dependent sentence' refers to semantically or syntactically nonautonomous sentences. 'Coordination' and 'subordination' describe the nature of the dependent sentence.

' I have borrowed the label 'situational dependency' from Stéphane Robert (1996: 154) from her article on the meanings of the aorist in Wolof where she describes the usage of the aorist "which never appears first in independent sentences; it is necessarily integrated via a preceding element which specifies the situational framework within which the narrative will unfold in the Aorist." [Translation by MD].

${ }^{\mathrm{vi}} \mathrm{M}$. Mithun (2008) compares two narratives, one in Yup'ik (same family as the Inuit continuum), the other in Navajo (Athabascan family): the Yup'ik narrative has 2 indicative forms for 25 subordinate clauses, whereas the Navajo narrative presents 17 indicative forms for 17 subordinate clauses.

vii There are two homophonous affixes -yaaq-, the verbal derivation affix "a lot" and the conjunctive morpheme "at the time when". It might well be that the distinct affixes yaaq- et -yiaq- 'each time that' tend to merge formally in Tunumiisut (M. Fortescue p.c.). There are numerous homophones in the affixes given the language's small phoneme inventory (three vowels i, a, u, and eleven consonants $\mathrm{p}, \mathrm{t}, \mathrm{s}, \mathrm{k} \mathrm{q}, \mathrm{m}, \mathrm{n}, \mathrm{y}, \mathrm{N}, \mathrm{w}, \mathrm{y})$ and the numerous cases of vowel and consonant assimilations. 